\title{
Access and Use of Digital Resources for Learning in a Digitized Upper Secondary School
}

\author{
Therése Haglind \\ The municipality of Jönköping, Sweden
}

\begin{abstract}
This paper presents findings about students' access and use of digital resources for learning in a digitized upper secondary school. The data comes from a project about a group of teachers working with a lesson design in order to integrate ICT in their teaching. A part of this lesson design was to use flipped movies for instruction and the discussion in this paper takes its starting point in the flipped movies. The access and use of this flipped movies are compared to other digital resources distributed to the students during the project.

Different kind of data material were used for this paper; a student survey, focus group interviews with students, teacher interviews, a group evaluation with teachers and logged activity on the $L M S$. For the analysis methodological triangulation was applied and the ecology of resources was used as an analytical lens.
\end{abstract}

\section{Introduction}

The ongoing digitalization of the society changes the conditions for education. Digital tools and other digital resources have in many schools become a part of the learning environment [10] and a part of the school infrastructure. Schools in Sweden are generally technology-rich, which here means that they are well equipped with digital tools $[4,10]$. Although there is high access to digital tools, studies show that the use of digital tools is relatively low. Hence, there is a gap between access and use $[5,8]$. Studies also show that there is a need not only for technical support but also for pedagogical support in order for teachers to use ICT in their teaching $[2,3,4]$.

The Swedish national agency for education state that it is important for teachers to reflect on their own teaching and to collaborate with other teachers [19]. Studies have shown the importance of teachers working together with the development of pedagogical ICT use [9]. The report "Innovative teaching and learning research: Findings and implications" shows that the collaboration is a key factor for education in today's technological society "Teacher collaboration that focuses on peer support and the sharing of teaching practices. Professional development that involves the active and direct engagement of teachers, particularly in practicing and researching new teaching methods. A school culture that offers a common vision of innovation as well as consistent support that encourages new types of teaching" [9] (p.12).

Modern technology is mandatory at both compulsory and upper secondary schools in Sweden [17, 18]. In Sweden a majority of the teachers think that they do not have sufficient ICT support and state that they need more service training in ICT and education.

A national IT -strategy for school in Sweden will be presented in spring 2016 by the Swedish National Agency for Education in order to ensure equal access to digital competence in school and to integrate ICT in education in order to support teaching and level up students' results. The use of digital learning resources, tools and working methods will for example be in focus in this ITstrategy.

Developmental changes can be discussed from a top down or a bottom up perspective and the flipped classroom can be seen as bottom up initiative. To flip your classroom has become a rather popular phenomenon among teachers in Sweden, and it is to be concerned as an initiative from the teachers as a way to work with modern technology and to give the students opportunities to develop their digital competence.

The digital technology enables instructional learning to take place both at school and at home. A student can prepare the instructional part of a lesson at home, which opens up for more student-centered activities at school [6, 7]. According to Hwang, Lai \& Wang [7] the students "play the role of active learners and make good use of assistance given by experts to elucidate relevant concepts" (ibid, p. 450). The Association of Flipped Learning Network [Association of FL] defines Flipped learning as follows:

"Flipped Learning is a pedagogical approach in which direct instruction moves from the group learning space to the individual learning space, and the resulting group space is transformed into a dynamic, interactive learning environment where the educator guides students as they apply concepts and engage creatively in the subject matter." 
According to Hamdan, McKnight, Mason, McKnight and Arfstrom [6] a concern about the Flipped classroom has been students' unequal access to technology. This case study has been carried out in a 1:1 school, which here means that the school has equipped all of the students and the teachers with a laptop to use both at home and in school for school related work.

This paper presents findings from a project about integrating ICT in education and it takes a starting point in a sociocultural perspective and in the understanding that learning is social and takes place in interaction with others and the world [15, 16] and that learning is enacted with mediating objects [16]. The ecology of resource model (EoR), which has its roots in the sociocultural perspective [13], is used as a theoretical lens. The Ecology of Resource Model (EoR) is a model that focuses on how technology can support and enhance learning in technology-rich environments [14]. The model can also be used to evaluate pedagogical use of technology [12]. EoR highlights three resource categories; Knowledge \& skills; Tools \& people and Environment.

"The ecology of Resources model /.../ describes the people, artefacts and environments with which the learner interacts as resources" [14].

Between the learner and the resources there are filters which can be both positive and negative, i.e. constrain or enable the use of the resources.

The flipped movie is in this paper identified as a resource, a tool, for the students to use. This paper presents findings from the case study and discusses both obstacles and hindrances for teachers to flip their classroom and discusses resource filters in relation to students' use of flipped movies as a resource for learning. In relation to this, this paper also presents findings about students` access and use of other digital resources distributed on the school LMS (Learning Management System) for the students to use in the lesson design in the case study, in order to see if there is a pattern in relation to student use of digital resources.

\section{Method}

The findings in this paper come from a case study where six teachers (two men and four women), in Swedish language at an upper secondary school in Sweden, worked together with a lesson design in order to integrate ICT in their teaching. All of the teachers in Swedish language at the school in the study were given the opportunity to participate and six of twenty teachers decided to participate. It was voluntary to be a part of the project, the only obligations was that the teachers should be interested to work with or try to work with ICT and digital technology in their lessons. Some additional teachers were interested but for different reasons, mainly due to time, they decided to decline participation in the project.

The case study was documented and selected findings are presented in this paper; from a student survey, focus group interviews with students, teacher interviews, a group evaluation with the teachers and logged activity on the LMS.

\subsection{Student survey}

The student survey contained of 24 questions and was conducted during a lesson and answered on paper with a pen. 109 of 139 students at their first year in upper secondary school answered the survey. The school had a total of 471 students in their first year that year, so 29, $5 \%$ of them participated in the study (see Table 1).

Table 1. Participants in the survey

\begin{tabular}{|l|c|}
\hline & Percent \\
\hline Women & $56 \%$ \\
Men & $43 \%$ \\
No answer & $1 \%$ \\
\hline Total & $99 \%$ \\
\hline
\end{tabular}

The students attended six different national programs: the Business Management and Economics Program (EK), the Social Science Program (SA), the Technology Program (TE), HVAC - the Property Maintenance Program (VF), Health and Social Care Program (VO) and the Vocational Introduction Program towards Health and Social Care (VI). EK; SA and TE are higher education preparatory programs. VF, VO and VI are vocational programs.

The analyses of the student survey were made in SPSS. For this paper five questions from the student survey were used:

1. Are you a female or a male?

2. What programme do you attend?

3. How do you best learn a new subject area?

4. What did you think about that the material to the work area sociolinguistics were on the LMS?

5. What did you think about your teacher recording his/her own movie?

6. Did you watch the movie/ the movies that your teacher recorded?

7. If you did not watch the movie/ the movies, why did you not watch the movie/ the movies?

\subsection{Focus groups interviews with students}

20 focus groups were conducted with a total of 62 students (35 women and 27 men). 
Table 2. The focus groups

\begin{tabular}{lllll}
\hline & Groups & N. & Women & Men \\
\hline EK & 3 & 7 & 4 & 3 \\
SA & 4 & 12 & 7 & 5 \\
VO & 4 & 15 & 15 & 0 \\
VF & 4 & 10 & 1 & 9 \\
TE & 4 & 12 & 3 & 9 \\
VI & 1 & 6 & 5 & 1 \\
Total & 20 & 62 & 35 & 27 \\
\hline
\end{tabular}

The questions for the focus group interviews revolve around four themes; "use of the school computer"; "the school LMS", "the subject area" (sociolinguistics) and "teaching and learning". The focus group interviews were digitally recorded and transcribed in Inqscribe.

\subsection{Teacher interviews and a teacher group evaluation}

In the end of the study the six teachers were individually interviewed and a group evaluation was also conducted. Both the interviews and the group evaluation were digitally recorded and transcribed in Inqscribe.

\subsection{Logged activity on the LMS}

The teachers distributed material, digital resources, on the school LMS (Learning Management System) for the students to use during the project. "This activity was logged, e.g. how many of the students who downloaded each resource were logged and counted, and the term use or used describe in this paper that activity.

Although this study could be concerned as a small scale study, the results can have a bearing on other similar contexts. Lindberg and Sahlin [11] state that "Generalizing from a single case may not be possible; however, case studies can have general importance" [11]. Case studies give unique examples from the practice or area in focus. For the analysis methodological triangulation was applied.

\section{Results}

The results will be presented in two parts. First the results from the teachers' perspective will be presented and after that the results from the students' perspective.

\subsection{Teachers about the flipped movies and digital resources on the LMS}

The teachers decided to distribute different kinds of digital resources for the students on the school
LMS (Learning Management System) as one way to integrate ICT in their lesson plan. They distributed for example word documents, web links and flipped movies on the LMS.

The teachers wanted to try the concept of flipping the classroom as a way to integrate the use of digital tools. Some of the teachers had heard of the concept before although none of them had tried it. They also wanted to do this because they identified educational benefits; (1) more time could be spent on discussions in the classroom and (2) the students could watch the movie more than one time.

The teachers also thought that it could be fun to try something new. Both benefits and obstacles were discussed beforehand. The two most distinctive obstacles for the teachers making the flipped movies were their own digital competence and time to both learn how to record and to record the flipped movie/ movies. They wrote a common manuscript both to facilitate the individual teachers' work and to give the classes a common base of knowledge. The teachers also shared pictures that could be used in the movie. To solve the technical problems in the process the ICT-pedagogue at the school assisted and one of the teachers in the group also provided technical support to her colleagues.

Four of six teachers made one or more flipped movies, or some kind of recording for the students. They chose different ways to do this; one teacher made a Power point and recorded audio to it and another used Movie Maker to make a movie. The movies were uploaded at the school learning management system (LMS). The school in the study did not at this time have software that enabled making flipped movies in a more advanced way.

The ambition in the beginning of the project was for all of the teachers to record flipped movies as a complement to providing the students with subject content, but for different reasons some of them did not record a flipped movie within this project. Others recorded more than one and stated that they will continue to do so even after the end of the project. Almost all of the teachers were positive towards flipping the classroom, however they were a bit unsure of how the students perceived the movies as resources for learning [13]. The following excerpt from the evaluation is used to highlight this:

"During the first lesson I told the students about the project and that I had recorded four movies that they would look at, that this was their homework. And that I had recorded the movies so that we would have more time to work in the classroom. But, when they came the next lesson, then none of them had watched the movie and they had not looked at it the next lesson either, and not the next after that" (Group evaluation with the teachers).

This is consistent with some of the findings from the students' perspective. 


\subsection{Students about digital resources in the LMS}

$71 \%$ of the student stated that it was very good or good the material to the work area was on the school LMS and thus in digital form. $21 \%$ stated that this was neither good nor bad and $6 \%$ that this was bad or very bad.

Table 3. Students' opinions about the material on the LMS

\begin{tabular}{|l|c|}
\hline & Percent \\
\hline Very good & $30 \%$ \\
Good & $41 \%$ \\
Neither good nor bad & $21 \%$ \\
Bad & $3 \%$ \\
Very bad & $3 \%$ \\
\hline Total & $98 \%$ \\
\hline
\end{tabular}

The four teachers in the case study distributed varied resources on the school LMS for their students. Table 4, 5, 6 and 7 show how many resources the teachers distributed what kind of resources and how many of the students used them.

Teacher 1 distributed 21 resources on the school LMS for the students (see Table 4). Three of these resources were Power points and one of them was a Flipped movie. $9.5 \%$ of the students used the "PPT 1 ", $3 \%$ used "PPT 2" and $3 \%$ used "PPT 3". $42 \%$ of the students watched the Flipped movie. Tables 4 also show that all of the students do not use all of the resources.

Table 4. Teacher 1 resources on the LMS

\begin{tabular}{|l|l|}
\hline Teacher 1 & $\begin{array}{l}\text { Students } \\
\text { Viewers } \\
\text { (n=31) }\end{array}$ \\
\hline Resource 1 - PPT (Power Point) & $9.5 \%$ \\
\hline Resource 2 - Web link & $6.5 \%$ \\
\hline Resource 3 - Word document & $35.5 \%$ \\
\hline Resource 4 - Word document & $3 \%$ \\
\hline Resource 5 - Word document & $48 \%$ \\
\hline Resource 6 - Web link & $84 \%$ \\
\hline Resource 7 - Word document & $19 \%$ \\
\hline Resource 8 - Web link & $77.5 \%$ \\
\hline Resource 9 - Word document & $42 \%$ \\
\hline Resource 10 - Web link & $13 \%$ \\
\hline Resource 11 - PPT (Power point) & $\mathbf{3 \%}$ \\
\hline Resource 12- MP4 (the Flipped Movie) & $\mathbf{4 2 \%}$ \\
\hline Resource 13 - Word document & $16 \%$ \\
\hline Resource 14 - Web link & $22.5 \%$ \\
\hline Resource 15 - PPT (Power point) & $\mathbf{3 \%}$ \\
\hline Resource 16 - Word document & $42 \%$ \\
\hline Resource 17 - Web link & $45 \%$ \\
\hline Resource 18- Web link & $0 \%$ \\
\hline Resource 19 - Word document & $16 \%$ \\
\hline Resource 20 - Word document & $16 \%$ \\
\hline Resource 21 - Word document & $3 \%$ \\
\hline & \\
\hline
\end{tabular}

Teacher 2 did not distribute a Flipped movie or PPT to the students on the school LMS. The resources for the students contained of word documents and web links. Resource 3, for example, is a link to a web page where the students can listen to different kind of dialects.

Table 5. Teacher 2 resources on the LMS

\begin{tabular}{|l|l|}
\hline Teacher 2 & $\begin{array}{l}\text { Students } \\
\text { Viewers (n=32) }\end{array}$ \\
\hline Resource 1 - Word document & $87.5 \%$ \\
\hline Resource 2 - Web link & $47 \%$ \\
\hline Resource 3 - Web link & $90.5 \%$ \\
\hline Resource 4 - Word document & $31 \%$ \\
\hline Resource 5 - Web link & $9 \%$ \\
\hline Resource 6 - Word document & $22 \%$ \\
\hline $\begin{array}{l}\text { Resource 7 - Word document } \\
\text { (pdf) }\end{array}$ & $19 \%$ \\
\hline Resource 8 - Word document & $47 \%$ \\
\hline
\end{tabular}

Teacher 3 distributed eight resources for the students. One of them were a Flipped movie and one of them a Power point. 9/11 students watched the Flipped movie and 10/17 used the Power Point.

Table 6. Teacher 3 resources on the LMS

\begin{tabular}{|l|l|}
\hline Teacher 3 & $\begin{array}{l}\text { Students } \\
\text { Viewers (n=17) }\end{array}$ \\
\hline Resource 1 - Word document & $12 \%$ \\
\hline Resource 2 - Word document & $12 \%$ \\
\hline Resource 3 - Word document & $6 \%$ \\
\hline Resource 4 - Word document & $6 \%$ \\
\hline Resource 5 - Word document & $0 \%$ \\
\hline Resource 6 - Word document & $70.5 \%$ \\
\hline Resource 7 - Word document & $12 \%$ \\
\hline Resource 8 - PPT (Power point) & $\mathbf{5 9 \%}$ \\
\hline
\end{tabular}

Teacher 4 distributed 26 resources to the students. The teacher did not record a Flipped movie but distributed three Power points for the students. $22 \%$ of the students used "PPT 1", $0 \%$ of the students used "PPT 2" and $16 \%$ of the students used "PPT 3".

Table 7. Teacher 4 resources on the LMS

\begin{tabular}{|l|l|}
\hline Teacher 4 & $\begin{array}{l}\text { Students } \\
\text { Viewers (n=32) }\end{array}$ \\
\hline Resource 1 - Word document & $19 \%$ \\
\hline Resource 2 -Web link & $6 \%$ \\
\hline Resource 3 - Web link & $3 \%$ \\
\hline Resource 4 - Word document & $12.5 \%$ \\
\hline Resource 5 - Web link & $12.5 \%$ \\
\hline Resource 6 - Word document & $6 \%$ \\
\hline Resource 7 - PPT (Power point) & $\mathbf{2 2} \%$ \\
\hline Resource 8 - Web link & $22 \%$ \\
\hline Resource 9 - Web link & $12.5 \%$ \\
\hline Resource 10 - Web link & $0 \%$ \\
\hline
\end{tabular}




\begin{tabular}{|l|l|}
\hline Resource 11 - PDF & $0 \%$ \\
\hline Resource 12 -PDF & $0 \%$ \\
\hline Resource 13 - PPT (Power point) & $\mathbf{0} \%$ \\
\hline Resource 14 - Word document & $0 \%$ \\
\hline Resource 15 - PDF & $0 \%$ \\
\hline Resource 16 - PPT (Power point) & $\mathbf{1 6} \%$ \\
\hline Resource 17 - Word document & $12.5 \%$ \\
\hline Resource 18 - Word document & $12.5 \%$ \\
\hline Resource 19-Word document & $0 \%$ \\
\hline Resource 20 - Web link & $0 \%$ \\
\hline Resource 21 - PDF & $0 \%$ \\
\hline Resource 22 - PDF & $6 \%$ \\
\hline Resource 23 - JPG (picture) & $6 \%$ \\
\hline Resource 24 - JPG (picture) & $3 \%$ \\
\hline Resource 25 - Web link & $16 \%$ \\
\hline Resource 26 - Web link & $9 \%$ \\
\hline
\end{tabular}

All of the six teacher distributed digital resources for the students to use on the school LMS. One of the teachers distributed 21 resources, two of the teachers distributed eight resources each and the forth teacher distributed 26 digital resources.

\subsection{Students about flipped movies}

The teachers introduced the Flipped movies as new way to give the students instructional knowledge. Usually they would give a lecture about the subject area, in this case Sociolinguistics. 38, 5 $\%$ of the students state that they prefer a traditional lecture about a new subject area, $15.5 \%$ stated that they prefer to work with question sheets and $15 \%$ state that they prefer watching a movie about the new subject area in order to learn the best.

Table 8. How do you best learn a new subject area?

\begin{tabular}{|l|c|}
\hline & Percent \\
\hline Traditional lecture given by the teacher & $38,5 \%$ \\
Watching a movie & $15 \%$ \\
Working with question sheets & $15,5 \%$ \\
Discussing with a friend & $14 \%$ \\
By teamwork & $3 \%$ \\
Others & $5,5 \%$ \\
\hline Total & \\
\hline
\end{tabular}

38, $5 \%$ of the students answered that they thought it was very good that the teacher recorded their own movie as a learning resource for them. 31 $\%$ thought it was good, $17 \%$ neither good nor bad and $7,5 \%$ thought it was a bad idea. But overall there were positive responses to this question; 69, 5 $\%$ of the students thought it was a very good or a good idea that the teacher made a movie in order to flip the classroom (see Table 9).
Table 9. What did you think about the teacher recording his/her own movie?

\begin{tabular}{|l|c|}
\hline & Percent \\
\hline Very good & $38,5 \%$ \\
Good & $31 \%$ \\
Neither good nor bad & $17 \%$ \\
Very bad & $7,5 \%$ \\
No answer & $6 \%$ \\
\hline Total & $100,0 \%$ \\
\hline
\end{tabular}

$73 \%$ of the students answered that they watched their teachers' movie or movies. $23 \%$ said that they did not do it (see Table 10). But to sum it up, the students showed a positive attitude to this question.

Table 10. Did you watch the movie/ the movies that your teacher recorded?

\begin{tabular}{|l|c|}
\hline & Percent \\
\hline Yes & $73 \%$ \\
No & $23 \%$ \\
No answer & $4 \%$ \\
\hline Total & $100,0 \%$ \\
\hline
\end{tabular}

10/52 students answered the question "If you did not watch the movie/ the movies, why did you not watch the movie/ the movies?" in the student survey. The Table 11 shows their answers.

Table 11. If you did not watch the flipped movie, why did you not watch the movie?

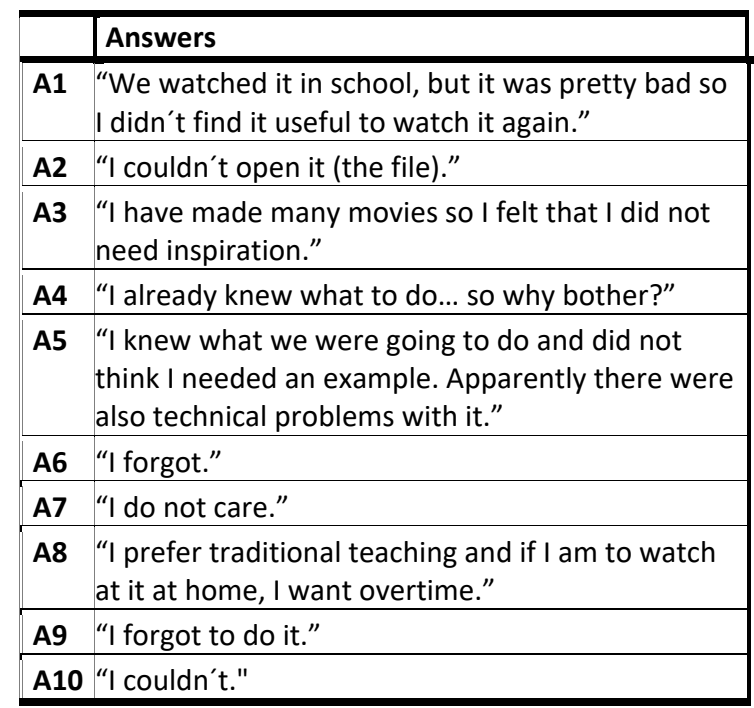

Looking at these answers and other answers from the focus group interviews it is clear that the students did not understand why the teachers recorded the flipped movie for them and they did not perceive the flipped movie as a learning resource. The lesson design for working with sociolinguistics contained an assessment for the 
students to make their own movie and the students made a connection between their assessment and the teacher movie.

A correlation between the question "What did you think of the teacher recording his/her own movie?" and "What programme do you attend" showed that the students attending VO (the Health and Social Care Programme) were the most positive in regard to this question. 8/11 answered that they thought that this was very good and $3 / 11$ that is was good. VO is a vocational programme and all of the 11 students (who answered this question in the student survey) were positive towards a digital form of content instruction. This picture is confirmed with the focus group interviews and the LMS activity $\log$. 9/11 of them also watched their teachers' movie.

The following excerpts, shown in Table 12, are from focus group interviews with the VO students.

Table 12. VO students' answers about flipped movies (excerpts from focus group interviews)

\begin{tabular}{|c|c|}
\hline Excerpts & \\
\hline E1 & $\begin{array}{l}\text { "You understood a bit more than } \\
\text { during a regular lesson." }\end{array}$ \\
\hline E2 & $\begin{array}{l}\text { "It is more fun to hear your own } \\
\text { teacher in a movie than any other } \\
\text { movie." }\end{array}$ \\
\hline E3 & $\begin{array}{l}\text { "It is good with a movie because we } \\
\text { can both see and listen." }\end{array}$ \\
\hline E4 & $\begin{array}{l}\text { "You learn more if you are familiar } \\
\text { with the voice." }\end{array}$ \\
\hline E5 & $\begin{array}{l}\text { "It would be good if more (teachers) } \\
\text { could do so (make a flipped movie) } \\
\text { because I have trouble catching } \\
\text { everything during a lesson." }\end{array}$ \\
\hline
\end{tabular}

\section{Discussion}

In the lesson design in this study, the knowledge and skills [14] concerned the subject area of sociolinguistics. The student should learn about dialects, sociolects and male and female language, in accordance with the curriculum for the course.

The teachers distributed different digital resources for the students on the school LMS. These resources are identified as tools in accordance to the Ecology of resource Model [13].

The students worked with this subject area both in school and at home, so at least in two different environments [13]. The student computer, distributed by the school for the students to use for school work both at home and at school, could thereby be used in different environments. The school computers give equal access to the digital resources.

The teachers flipped the classroom because they wanted to try something new that some of them had heard about, but none of them had tried before. The group gave them both time, opportunity and support to do this. Working together with a lesson design through collegial cooperation, the teachers also got something specific to have for example pedagogical and didactic discussions about. Hwang, Lai and Wang state that:

"Certainly, being a pioneer of flipped learning needs both time and effort. Teachers need to inspect the teaching contents and analyse the essence and objectives of teaching, which can use technology and teaching strategies more appropriately" [7].

The teachers also saw this as a way to implement ICT in their teaching and they could see educational benefits with it. When the students get the content beforehand, the teacher can use more of the time in the classroom answering questions and having discussions with the students; making the students more active and move from a teachercentered to a more student-centered classroom.

In the process of flipping, both obstacles and enablers were identified. Most of the teachers did not know how to record a movie and this is here identified as an obstacle for flipping the classroom. One key factor was the school ICT-pedagogue at the school who helped the group with technical problems. Another key factor was that the members in the group helped each other. They who knew a bit more about recording, helped the others. This coincides with Vygotsky's concept of the Zone of proximal development (ZPD) [20]. Luckin also argues for the role of the more able partners (MAP) to develop learning [13].

One other obstacle identified in this study concerns time. One of the teacher did not make a flipped movie because he perceived that there was no time for him to do so. The teachers who did record their own movie or movies raised that it took a lot of time making the flipped movie; first to figure out how to do it technically, then to decide the on the content and after that to make the actual recording or recordings. These teachers stated that they had to take time to do this from their working hours. An enabler was that the group created a manuscript for all of them to use and that they shared pictures that they could use in their movies.

The teachers wanted to try a new way of giving the students the instructions and "the basic knowledge" about the subject area, and in this case study they tried the concept of flipping the classroom. Four of the six teachers recorded their own movies and distributed them for the students, but although the students were positive, not all of the students watched them.

The students were generally positive towards the flipped movies. 69, $5 \%$ of the students answered that they thought it was a very good or a good idea that the teachers recorded their own movie and 73 $\%$ of the students answered that they watched their teacher's movie or movies. Students explain not 
watching the movies with answers like "I forgot" or "I already knew what to do... so why bother?". They stated that they forgot it or that they did not feel that they needed it, in other words that they did not need the movie as a resource.

$71 \%$ of the students stated in the student survey that it was good or very good that the material was distributed on the school LMS. But looking at the logged activity of the use of the resources (i.e. how many students who downloaded the material) the overall figures are not that high.

In accordance with EoR, the Flipped movies are in this paper identified as a resource, a tool for learning [12] and both positive and negative filters are identified. The school has provided each student with a digital tool, which means that all of the students have access to a digital tool in order to watch the flipped movie any time, any place and this is here identified as a positive filter. Although having access to the flipped movie some of the students did not use it as a resource for learning because they did not think they needed to, because they had technical problems or because they did not want to. In this paper this is identified as a negative filter. One possible explanation for this could be how the students perceive digital tools as resources for learning.

Besides the flipped movies, the six teacher distributed other kinds of digital resources (mostly word documents and web links) on the school LMS for the students to use. $71 \%$ of the students stated that they think it was very good or good that the material for the subject area, sociolinguistics, were on the school LMS. Although, the findings in this paper show that, regardless to access to digital resources, the use of them varied. The students did not use all of the available resources for instruction. Some of the resources, made available by the teacher, were not used by a single student. Students not using the digital resources is identified as a negative filter.

In relation to the discussion about the flipped movies, it is interesting to compare the student use of the Power points since they partly serve the same purpose; giving the students instruction about the subject area. And the findings show that most of the students did not use the Power points although they had access to them.

\section{Conclusion}

The Flipped classroom could be a way to make the lessons more student-oriented even in a formal setting at the same time as furthering training the students' digital competence. To enter the lesson prepared in formal education is nothing new, what is new is using modern technology to do it. Säljö [16] argues:
"Not even the most powerful information technology solves the problem of learning, it just changes the terms of it" [16].

Flipping the classroom can be seen as a developmental initiative bottom up and can be identified as a way to integrate the use of digital resources in the classroom and also an opportunity for students to use digital resources.

Schools can build up digital infrastructures and provide a vide repertoire of resources, but it is crucial that the students also use the resources provided for them and here it is important to discuss aspects such as students' access to digital tools, their digital competence and their perceptions of digital technology for learning purposes in a formal setting. The school infrastructure is build up by different kinds of resources, some of them are digital and some of them are not. The findings in this paper show that the students use the digital resources in varied degree. The findings also indicate that the meetings in the classroom are important for the students to receive instructional knowledge and instruction about the subject area. The findings indicate that in this face-to-face environment, the digital resources can be identified as a complement to other resources.

When integrating the use of ICT in teaching there is a risk that technical problems or issues get in focus and not the pedagogical aspects. When the question about access to digital resources is equal and taken care of, then it is about time to focus on the pedagogical and educational issues.

\section{References}

[1] Association of Flipped Learning Network. (2014). What is flipped learning?http://flippedlearning.org/ domain/46; (18 January 2016).

[2] Balanskat, A., Blamire, R., \& Kefala, S. (2006). The impact report $-A$ review of studies of ICT impact on schools in Europe. In European Scoolnet (Ed).

[3] Bingimlas, K. A. (2009). Barriers to the Successful Integration of ICT in Teaching and Learning Environments: A Review of the Literature. Euroasia Journal of Mathematics, Science \& Technology Education, 5(3), 235-245.

[4] European Schoolnet. (2013). Survey of schools: ICT in Education. Benchmarking access, use and attitudes to technology in Europe's schools. Final Study Report. Retrieved 2013-10-05 from https://ec.europa.eu/digitalagenda/sites/digital-agenda/files/KK-31-13-401-ENN.pdf.

[5] Haglind, T. (2015). Digitalisering av skolans verksamhet: tillgång och användning. (Licentiate thesis). University of Gothenburg.

[6] Hamdan, N., McKnight, P., Mason, G., McKnight, K. \& Arfstrom, K. (2013). A review of flipped learning. Pearson. 
[7] Hwang, G-J., Lai, C-L. \& Wang, S-Y. (2015). Seamless flipped learning: a mobile technology enhanced flipped classroom with the effective learning strategies. Journal of Computer Education, 2(4): 449-473.

[8] Hylén, J. (2013). Digitalisering i skolan - en kunskapsöversikt. Stockholm. Ifous rapportserie 2013:1.

[9] ITLresearch. (2011). Innovative Teaching and Learning Research 2011 Findings and Implications. http://www.itlresearch.com/research-a-reports,

February 2013).

[10] Jensen, L. J. \& Kummer, T. A. \& Codoy, P. (2015). Improvements from a Flipped Classroom May Simply Be the fruits of Active Learning. CBE - Life Sciences Education, vol 14, 1-12.

[11] Lindberg, J.O., \& Sahlin, S. (2011). Bridging school-subjects and distance in upper secondary schools. Campus-Wide Information Systems, 28(3), 144-153.

[12] Luckin, R. (2008). The learner centric ecology of resources: A framework for using technology to scaffold learning. Computers \& Education, 50(2), 449-462.

[13] Luckin, R. (2010). Re-designing Learning Contexts: technology-rich, learner-centered ecologies. New York: Routledge.

[14] Luckin, R. \& Clark, W. (2011). More than a game: The participatory Design of contextualized technologyrich learning experiences with the ecology of resources. Journal of e-learning and Knowledge Society, English Edition, 7(3), 33-50.

[15] Sutherland, R., Lindström, B., \& Lahn, L. (2009). Sociocultural Perspectives on Technology-Enhanced Learning. I Balacheff et al. (Ed), Technology-enhanced learning, 39-53. Springer.

[16] Säljö, R. (2014). Lärande $i$ praktiken - ett sociokulturellt perspektiv. Studentlitteratur AB, Lund.

[17] The Swedish National Agency for Education. (2011a). Läroplan för grundskolan, förskoleklassen och fritidshemmet; www.skolverket.se/publikationer (17 October 2012).

[18] The Swedish National Agency for Education. (2011b). Läroplan för gymnasieskolan 2011; www.skolverket.se/publikationer (17 October 2012).

[19] The Swedish National Agency for Education. (2012) Matematiklyftet; http://www.skolverket.se/publikationer (31 January 2013).

[20] Vygotsky, L.S. (1978). Mind in society. The development of higher psychological process. Harvard University Press. 